OPEN ACCESS

Edited by:

Sebastian Leuzinger

Auckland University of Technology,

New Zealand

Reviewed by:

Hans J. De Boeck,

University of Antwerp, Belgium

Rubén Retuerto,

Universidade de Santiago

de Compostela, Spain

*Correspondence:

Wei Sun

sunwei@nenu.edu.cn

Specialty section:

This article was submitted to

Functional Plant Ecology,

a section of the journal

Frontiers in Plant Science

Received: 06 November 2017

Accepted: 12 February 2018

Published: 27 February 2018

Citation:

Shi B, Wang Y, Meng B, Zhong S and Sun W (2018) Effects of Nitrogen Addition on the Drought Susceptibility

of the Leymus chinensis Meadow

Ecosystem Vary with Drought

Duration. Front. Plant Sci. 9:254.

doi: $10.3389 / f p / s .2018 .00254$

\section{Effects of Nitrogen Addition on the Drought Susceptibility of the Leymus chinensis Meadow Ecosystem Vary with Drought Duration}

\author{
Baoku Shi', Yunbo Wang ${ }^{1,2}$, Bo Meng ${ }^{1}$, Shangzhi Zhong ${ }^{1}$ and Wei Sun ${ }^{1 *}$ \\ 1 Key Laboratory for Vegetation Ecology, Ministry of Education, Institute of Grassland Science, Northeast Normal University, \\ Changchun, China, ${ }^{2}$ Key Laboratory of Grassland Resources, Ministry of Education, College of Grassland, Resources and \\ Environment, Inner Mongolia Agricultural University, Hohhot, China
}

It is not clear yet how extreme drought and nitrogen $(\mathrm{N})$ deposition influence grassland ecosystem functions when they are considered together, especially in complex field conditions. To explore the response of the Leymus chinensis meadow ecosystem to manipulated extreme drought (45 days), $\mathrm{N}$ addition and their interaction, we measured leaf photosynthetic characteristics, aboveground phytomass on the community level and ecosystem $\mathrm{C}$ exchange in different treatments at the middle and the end of the drought period. The extreme drought treatment decreased the leaf net $\mathrm{CO}_{2}$ assimilation rate and ecosystem $\mathrm{C}$ exchange [gross ecosystem productivity (GEP), ecosystem respiration and net ecosystem $\mathrm{CO}_{2}$ exchange]. In contrast, the $\mathrm{N}$ addition treatment increased aboveground phytomass, GEP and net ecosystem $\mathrm{CO}_{2}$ exchange. The effects of $\mathrm{N}$ addition on the drought susceptibility of the $L$. chinensis meadow ecosystem varied with drought severity. The $\mathrm{N}$ addition treatment alleviated droughtinduced suppression of $\mathrm{CO}_{2}$ exchange at the leaf and ecosystem levels in the middle of the drought period, whereas it exacerbated drought-induced suppression of the $\mathrm{CO}_{2}$ exchange and aboveground phytomass on the community level at the end of the drought period. Given that dominance by $L$. chinensis is a characteristic of the studied ecosystem, knowledge of the traits of $L$. chinensis and its response to multiple global change drivers will be crucial for predicting future ecosystem functions. Furthermore, increasing $\mathrm{N}$ deposition may affect the response of the $L$. chinensis meadow ecosystem to further droughts by increasing carbon allocation to roots and therefore root-shoot ratios.

Keywords: climate change, nitrogen deposition, extreme drought, phytomass, ecosystem C exchange, ecosystem functions, saline-alkaline grassland

\section{INTRODUCTION}

Anthropogenic activities strongly influence environmental change, including discrete climate extremes (e.g., drought and torrential rainfall) and chronic environmental changes (e.g., $\mathrm{N}$ deposition and increasing $\mathrm{CO}_{2}$ concentration) (IPCC, 2013; Zhu et al., 2016). Many terrestrial ecosystems, including grasslands, face unprecedented shifts in these environmental conditions and are affected by discrete climate extremes and chronic environmental changes, as well as their 
interactions, with unknown consequences for ecosystem functions and services (livestock forage production, biodiversity preservation and $\mathrm{C}$ sequestration) (Smith, 2011, Lee et al., 2014; Hufkens et al., 2016; Smith et al., 2016). Thus, understanding how grassland ecosystems respond to multiple global change drivers is important.

In temperate regions, drought events are expected to increase in intensity and/or duration due to climate change (IPCC, 2013). Both linear and non-linear models show a strong correlation between drought and grassland productivity (Knapp et al., 2017). Drought induces decreases in the soil water content and increases in plant water deficit, which cause subsequent decreases in the leaf carbon assimilation rate and soil available nutrients, leading to plant $\mathrm{N}$ limitation and earlier senescence and mortality of tissues, further reducing plant aboveground productivity and net ecosystem $\mathrm{CO}_{2}$ exchange (NEE) (Durand et al., 2010; Yi et al., 2015; Hofer et al., 2016; Hoover et al., 2017). Grassland ecosystems face both extreme drought events and other global change drivers, of which increasing $\mathrm{N}$ deposition strongly influences aboveground productivity and carbon cycles (Niu et al., 2010; Ladwig et al., 2012). Atmospheric N deposition has increased by nearly five times in China from 1901 to 2005 and is expected to further increase in coming decades (Lu et al., 2012). Plants are commonly N-limited in grassland ecosystems (LeBauer and Treseder, 2008). As such, enhanced atmospheric $\mathrm{N}$ deposition increases soil available $\mathrm{N}$, alleviates plant $\mathrm{N}$ limitation and stimulates leaf photosynthesis (Evans, 1989), further increasing plant aboveground productivity and NEE (Niu et al., 2010). The combination of extreme drought and $\mathrm{N}$ addition may not act additively but produce nonadditive interrelated effects on ecosystem responses (MeyerGrünefeldt et al., 2015). Many studies have suggested that $\mathrm{N}$ addition could make grassland ecosystems more vulnerable to extreme drought events (Xu et al., 2014; Song and $\mathrm{Yu}$, 2015). This is because $\mathrm{N}$ addition causes a disproportionate increase in aboveground phytomass and more evaporative water loss, thus increasing the likelihood of drought stress (Friedrich et al., 2012; Southon et al., 2012). However, the effects of $\mathrm{N}$ addition on drought sensitivity of grassland ecosystems may depend on the drought intensity and/or duration (Knapp et al., 2008; Greaver et al., 2016). In the early stages of drought, the amount of water in the soil is relatively sufficient, which may induce mild drought stress on plants. Meanwhile, N addition associated with greater leaf $\mathrm{N}$ content and water use efficiency could partially compensate for drought-induced suppression. With the intensification of drought stress, $\mathrm{N}$ addition is likely to exacerbate drought effects due to higher phytomass, related greater water consumption and a lower rootshoot ratio associated with a reduced ability to acquire new water sources. However, this hypothesis has not been tested yet.

Furthermore, most studies on the effects of extreme drought and/or $\mathrm{N}$ addition focus at a single level of biological organization, e.g., at the physiological level (Flexas et al., 2008) or on the community level (Hoover et al., 2015). These manipulation experiments focusing on a single level cannot give a complete picture of the effects of multiple stressors on grassland ecosystems
(Reyer et al., 2013). The effects of drought and/or $\mathrm{N}$ addition are predicted to begin at the gene expression or metabolomics level and translate up to higher hierarchical levels (Smith et al., 2009; Peñuelas et al., 2017). Here, we focus on how leaf photosynthetic characteristics respond to drought and/or $\mathrm{N}$ addition and whether these individual level physiological responses can translate to community and ecosystem level responses.

Leymus chinensis meadow steppe, located on the eastern edge of the Euro-Asian grassland, is the most typical grassland type in northeast China (Zhu, 2004; Zhang et al., 2013). Soil water content and soil $\mathrm{N}$ availability are the primary limiting factors for plant growth in L. chinensis meadow steppe because of the limited rainfall and widespread distribution of saline alkali soil (Wang et al., 2015). The extreme drought and $\mathrm{N}$ addition treatments were performed in a L chinensis meadow steppe, which provided an opportunity to explore the response of leaf photosynthetic characteristics and ecosystem functions (species diversity, aboveground productivity and ecosystem $\mathrm{C}$ exchange) to these stressors under in situ conditions. We hypothesized that (1) leaf carbon assimilation, aboveground phytomass and ecosystem $\mathrm{C}$ exchange decline in response to extreme drought; (2) leaf carbon assimilation, aboveground phytomass and ecosystem $\mathrm{C}$ exchange increase under the $\mathrm{N}$ addition treatment; and (3) $\mathrm{N}$ addition alters the drought sensitivity of the L. chinensis meadow ecosystem, and the effects are likely to vary with drought duration.

\section{MATERIALS AND METHODS}

\section{Ethics Statement}

No specific permissions were required for the field studies described, because the Songnen Grassland Ecological Research Station is a department of the Northeast Normal University. No specific permissions were required for the study either, as it was conducted in accordance with the guidelines set by the Northeast Normal University. No specific permissions were required for the locations or the activities. No location was privately owned or protected in any way, and the field studies did not involve endangered or protected species.

\section{Study Area}

The study was conducted in the Songnen Grassland Ecology Research Station $\left(44^{\circ} 45^{\prime} \mathrm{N}, 123^{\circ} 45^{\prime} \mathrm{E}\right)$, Jilin Province, northeastern China. The study site has a temperate semiarid monsoon climate. The mean annual temperature is $6.4^{\circ} \mathrm{C}$ (1950-2004). The mean annual precipitation is $471 \mathrm{~mm}$ (1950-2004), which is concentrated in the summer (JuneAugust). The duration of the frost-free season is 150 days. The studied grassland has a sodic saline meadow soil with a $\mathrm{pH}$ value of 8.0-9.0, soil organic carbon content of $2.0 \%$ and soil total nitrogen content of $0.15 \%$ (Wang et al., 2015). The vegetation of the studied meadow steppe is primarily composed of L. chinensis; Phragmites australis, Chloris virgata, and Kalimeris integrifolia are also 
present at lower densities (Zhang et al., 2013; Cui et al., 2015).

\section{Experimental Design}

Before 2009, the studied grassland was lightly grazed by large livestock herds dominated by cattle and sheep, and was mowed each fall. In 2009, the studied grassland, with an area of $100 \mathrm{~m} \times 100 \mathrm{~m}$, was fenced to avoid grazing and mowing. Within the fenced grassland, six experimental blocks were randomly established in April 2011. Each block consisted of two $10 \mathrm{~m} \times 10 \mathrm{~m}$ plots, which were separated by a $5 \mathrm{~m}$ wide buffer strip. Each plot was randomly assigned to the fertilized or unfertilized treatments. The atmospheric $\mathrm{N}$ deposition in the temperate grassland ecosystems in northern China was as high as $2.7 \mathrm{~g} \mathrm{~N} \mathrm{~m}^{-2} \mathrm{yr}^{-1}$ in recent 10 years (Bai et al., 2010). The studied grassland is surrounded by cropland which is often over-fertilized by $\mathrm{N}$; thus, there are probably large emissions of nitrogenous pollutants by volatilization, denitrification, etc., and atmospheric $\mathrm{N}$ (re)deposition is more significant than in other grassland areas (He et al., 2007). Moreover, the community saturation $\mathrm{N}$ deposition rate was approximately $10.5 \mathrm{~g} \mathrm{~N} \mathrm{~m}^{-2} \mathrm{yr}^{-1}$ in this temperate grassland ecosystem (Bai et al., 2010). As such, $\mathrm{N}$, in the form of urea, was applied five times yearly (May-September) at a rate of $10 \mathrm{~g}$ $\mathrm{N} \mathrm{m}^{-2} \mathrm{yr}^{-1}$ to the $\mathrm{N}$ addition treatment plots from 2011 to 2016.

Leymus chinensis, the dominant species of the Songnen meadow steppe, is a rhizomatous grass that uses the $C_{3}$ photosynthetic pathway (Zhong et al., 2017). To avoid summer high temperatures, it has a relatively short growing season and completes its breeding season before July. The daily growth rate of $L$. chinensis peaks in the middle of June, then begins to decline, and it stops growing in late July (Supplementary Table S1; Zhu, 2004). An extreme drought event was simulated from day 152 (1 June) to day 196 (15 July) in 2015 because the growth of $L$. chinensis in this period is sensitive to the water supply. Two $3 \mathrm{~m} \times 3 \mathrm{~m}$ subplots were established within each plot $(10 \mathrm{~m} \times 10 \mathrm{~m})$ in 2015 and were randomly assigned to the extreme drought treatment or the ambient precipitation treatment. On the outside edges of the extreme drought subplots, we dug a trench to a depth of $50 \mathrm{~cm}$. To prevent root growing out from the trenched subplots, surface runoff and the lateral flow of soil water, we lined the trenched subplots with a $2-\mathrm{mm}$ corrosion resistant plate and then refilled the soil back into the trench. The extreme drought was achieved using $3.5 \mathrm{~m} \times 3.5 \mathrm{~m}$ wide rainout shelters with slanted roofs (1 m tall) composed of transparent acrylic sheets ( $>90 \%$ light permeability). After the simulated extreme drought event, we carried out irrigation (four times) from late July to late August according to the amount of precipitation during the drought period to equalize the annual precipitation. The irrigation was carried out 1 week after the end of the drought treatment. In this week, there was no natural precipitation event; thus, the drought treatment lasted a week longer (to day 202). Our experimental design was fully factorial with four treatments: a $\mathrm{N}$ addition treatment $(\mathrm{N})$, a drought treatment (D), a combination of $\mathrm{N}$ addition and drought treatment (DN), and a control (C). Soil properties for the four treatments in 2014 are summarized in Supplementary Table S2.

\section{Micro-climate}

Precipitation and air temperature (at a height of $1 \mathrm{~m}$ above the ground) were measured hourly by a rainfall recorder and temperature sensor (RG2-M, Onset, Bourne, MA, United States) during the drought period in 2015. The soil temperature and soil water content at a depth of $10 \mathrm{~cm}$ in each subplot $(\mathrm{N}, \mathrm{D}$, $\mathrm{DN}$ and $\mathrm{C}$ ) in the selected representative block were measured hourly by a soil moisture probe (S-SMC-M005, Onset, Bourne, MA, United States) and a soil temperature probe (S-TMB-M006, Onset, Bourne, MA, United States), respectively, during the growing season (early June to late August) in 2015.

\section{Leaf Photosynthetic Characteristics}

The $\mathrm{CO}_{2}$ and water flux at the leaf level and ecosystem level were measured using portable $\mathrm{CO}_{2}$ infrared gas analyzers (LI-6400, LI-COR Inc., Lincoln, NE, United States). To reduce the time required for each measurement campaign, two LI-6400 analyzers (IRGA) were used for the gas exchange measurements (one for the leaf level and the other one for the ecosystem level). The net $\mathrm{CO}_{2}$ assimilation rate $(A)$, stomatal conductance $\left(g_{s}\right)$ and transpiration rate $\left(T_{r}\right)$ of $L$. chinensis were measured on day 173 (day 22 of the drought period) and 196 (day 45 of the drought period) in 2015. For each treatment, 18 individuals (three individuals in each subplot, six replications) were measured for each sampling campaign. For each individual plant, an upper most fully expanded leaf was used for the leaf gas exchange measurements. Measurements were performed from 7:30 to 11:30 AM. To avoid bias from the time of day, we measured six blocks (each block contained four treatments) sequentially. As such, the differences of time of measuring among treatments within a block were negligible. To limit the effects of fluctuations in light intensity and the atmospheric $\mathrm{CO}_{2}$ concentration on leaf photosynthetic characteristics, photosynthetically active radiation and the $\mathrm{CO}_{2}$ concentration were held at $1500 \mu \mathrm{mol}$ $\mathrm{m}^{-2} \mathrm{~s}^{-1}$ and $400 \mu \mathrm{mol} \mathrm{mol}^{-1}$, respectively. The temperature and relative humidity in the leaf chamber were maintained at ambient values.

\section{Ecosystem C and Water Flux}

A square aluminum frame $(0.5 \mathrm{~m} \times 0.5 \mathrm{~m})$ was inserted into the soil (to a depth of $3 \mathrm{~cm}$ ) in each subplot in May 2015. Ecosystem $\mathrm{C}$ and water fluxes were measured on day 173 and 196 in 2015 using an IRGA with a transparent chamber $(0.5 \mathrm{~m} \times 0.5 \mathrm{~m} \times 1.0 \mathrm{~m})$. The chamber was placed on the frame surface during the measurement. For measuring NEE and evapotranspiration (ET), the chamber was set on the frame for $2 \mathrm{~min}$, and the fluxes were determined from changes in the $\mathrm{CO}_{2}$ and water vapor concentrations recorded at $10 \mathrm{~s}$ intervals. Then, the chamber was vented and placed on the same frame used for ecosystem respiration (ER) measurements. The chamber was covered by an opaque cloth to eliminate light. The ER was determined from changes in the $\mathrm{CO}_{2}$ concentration recorded at $10 \mathrm{~s}$ intervals for $2 \mathrm{~min}$. Gross ecosystem productivity (GEP) was calculated as ER - NEE. The water-use efficiency (WUE) 
was calculated as -NEE/ET. In May 2015, one polyvinyl chloride collar (10.4 cm diameter $\times 6 \mathrm{~cm}$ height) was inserted into the soil in each subplot for soil respiration (SR) measurements. The aboveground parts of all plants inside the soil collars were clipped 1 day before the SR measurements. SR was also measured on days 173 and 196 in 2015 using an IRGA. The measurements of NEE, ER, ET, and SR were carried out from 7:30 to 11:30 AM. Ecosystem $\mathrm{CO}_{2}$ exchanges were measured sequentially for the six blocks.

\section{Plant Composition and Phytomass}

The vegetation was surveyed on day 196 in 2015 and in August 2016. Three $0.5 \mathrm{~m} \times 0.5 \mathrm{~m}$ quadrats in each subplot were randomly selected to survey plant species and an individual number of each species. Using the vegetation survey data, we calculated the species richness and the Shannon-Wiener index (Krebs, 1985):

$$
H=-\sum_{i=1}^{S} P_{i} \ln P_{i}
$$

where $H$ is the Shannon-Wiener index, $P_{i}$ is the proportion of the individual number for $i$ species over the individual number of all species, and $S$ is the number of species.

Following the vegetation survey, the aboveground phytomass (both living and dead) was harvested in one of three $0.5 \mathrm{~m} \times 0.5 \mathrm{~m}$ quadrats. Because the leaves were not withered completely during the drought period, the aboveground phytomass was not separated into pure biomass and necromass. Two soil cores $(5.5 \mathrm{~cm}$ diameter $\times 30 \mathrm{~cm}$ depth) were taken to estimate root phytomass using a root corer in the same quadrat. Next, the roots in the soil cores were collected, dried at $60^{\circ} \mathrm{C}$ to a constant mass, and weighed. The root-shoot ratio was calculated as root phytomass/shoot phytomass.

\section{Assessment of Drought Impact}

The effects of extreme drought on leaf photosynthetic characteristics, phytomass on the community level and ecosystem $\mathrm{C}$ exchange in the unfertilized or fertilized plots were quantified as the percentage change in these variables (\% Impact-D). Impact-D was calculated from Equation (2):

$$
\text { Impact }-\mathrm{D}=\left(\frac{X_{\mathrm{D}}-X_{\mathrm{C}}}{X_{\mathrm{C}}}\right) \times 100, \mathrm{OR}=\left(\frac{X_{\mathrm{DN}}-X_{\mathrm{N}}}{X_{\mathrm{N}}}\right) \times 100
$$

where $X_{C}, X_{D}, X_{N}$, and $X_{D N}$ are $A, g_{s}, T_{r}$, aboveground phytomass, root phytomass, root-shoot ratio, GEP, ER, NEE, ET, WUE, or SR in the $\mathrm{C}, \mathrm{D}, \mathrm{N}$, and $\mathrm{DN}$ plots, respectively.

\section{Data Analysis}

Data were tested for normality using a Kolmogorov-Smirnov test and for variance homogeneity using Levene's test. The effects of $\mathrm{N}$ addition, drought and measuring time on $A, g_{s}, T_{r}$, GEP, ER, NEE, ET, and WUE were analyzed using a repeatedmeasures analysis of variance (ANOVA), with $\mathrm{N}$ addition and drought as the between-subjects factors and measuring time as the within-subject factor. Comparisons of the means of response variables related to treatments $(C, D, N$, and $D N)$ in each measurement campaign were analyzed with an ANOVA combined with Tukey's post hoc test. A paired sample $t$-test was used to assess differences in the change in leaf, community and ecosystem response variables induced by drought (Impact-D) between the fertilized and unfertilized plots. A linear regression analysis was used to examine dependence of the $A, g_{s}$, and $T_{r}$ on the soil water content as well as relationships between the GEP and NEE and aboveground phytomass. All statistical analyses were conducted with the SPSS 18.0 software (SPSS Inc., Chicago, IL, United States). Graphs were generated using the SigmaPlot 12.5 software (Systat Software Inc., San Jose, CA, United States).

\section{RESULTS}

\section{Precipitation and Soil Water Content}

The amount of precipitation was $104.6 \mathrm{~mm}$ during the extreme experimental drought period (days 152-196; Figure 1A). The air temperature varied substantially during the experimental period (Figure 1A). As a result of shading effects of greater aboveground phytomass and cover, the soil temperatures $(10 \mathrm{~cm})$ in the $\mathrm{N}$ and $\mathrm{DN}$ plots were lower than in the $\mathrm{C}$ and $\mathrm{D}$ plots (Figure 1B). The seasonal variation of the soil water content in the $\mathrm{C}$ and $\mathrm{N}$ treatments depended on the occurrence of rainfall events (Figure 1C). The $\mathrm{N}$ addition, drought and combination of $\mathrm{N}$ addition and drought treatment had a strong effect on the soil water content, and the soil water contents in the N, D, and DN plots were 28,43 , and $52 \%$ lower than that in the $\mathrm{C}$ plots on day 196 (the end of the drought period), respectively.

\section{Leaf Gas Exchange}

In the middle of the drought period (day 173, 2015), the $\mathrm{N}$ addition, drought and combination of $\mathrm{N}$ addition and drought treatments had no significant effects on $A, g_{s}$, and $T_{r}$ compared to the $\mathrm{C}$ treatment $(P>0.05$; Figures $2 \mathrm{~A}, \mathbf{C}, \mathbf{E})$. At the end of the drought period (day 196, 2015), the drought treatment significantly reduced $A$, regardless of whether it was in the fertilized or unfertilized plots (Figure 2B). The DN treatment had the lowest $A, g_{s}$, and $T_{r}$ values on day 196 in 2015. The $A, g_{s}$, and $T_{r}$ varied with sampling dates, and $A, g_{s}$, and $T_{r}$ were lower on day 196 than on day 173 in 2015 (Figure 2 and Supplementary Table S3). Drought-induced reductions in $A, g_{s}$, and $T_{r}$ were lower in the fertilized plots (Impact-D: $-20,-16$, and $-12 \%$ ) than in the unfertilized plots (Impact-D: $-24,-29$, and $-25 \%$ ) on day 173 in 2015 (Figures 2A,C,E). However, this pattern was different on day 196 in 2015, with greater droughtinduced changes in $A, g_{s}$, and $T_{r}$ in the fertilized plots (Impact-D: $-39,-45$, and $-43 \%)$ than in the unfertilized plots (Impact-D: $-33,-32$, and $-30 \%$ ) (Figures 2B,D,F). On day 173 in 2015, we detected a marginally significant positive dependence of $g_{s}$ and $T_{r}$ on soil water content $(P<0.1$; Figure 3$)$, while the relationships between soil water content and $A$ were not statistically significant $(P=0.531$; Figure 3$)$. At the end of the drought period, we found a marginally significant positive dependence of $A, g_{s}$, and $T_{r}$ on the soil water content $(P<0.1$; Figure 3$)$.

Relationships between GEP (A) and ecosystem $\mathrm{CO}_{2}$ exchange (NEE) (B) and aboveground phytomass across all the treatments 

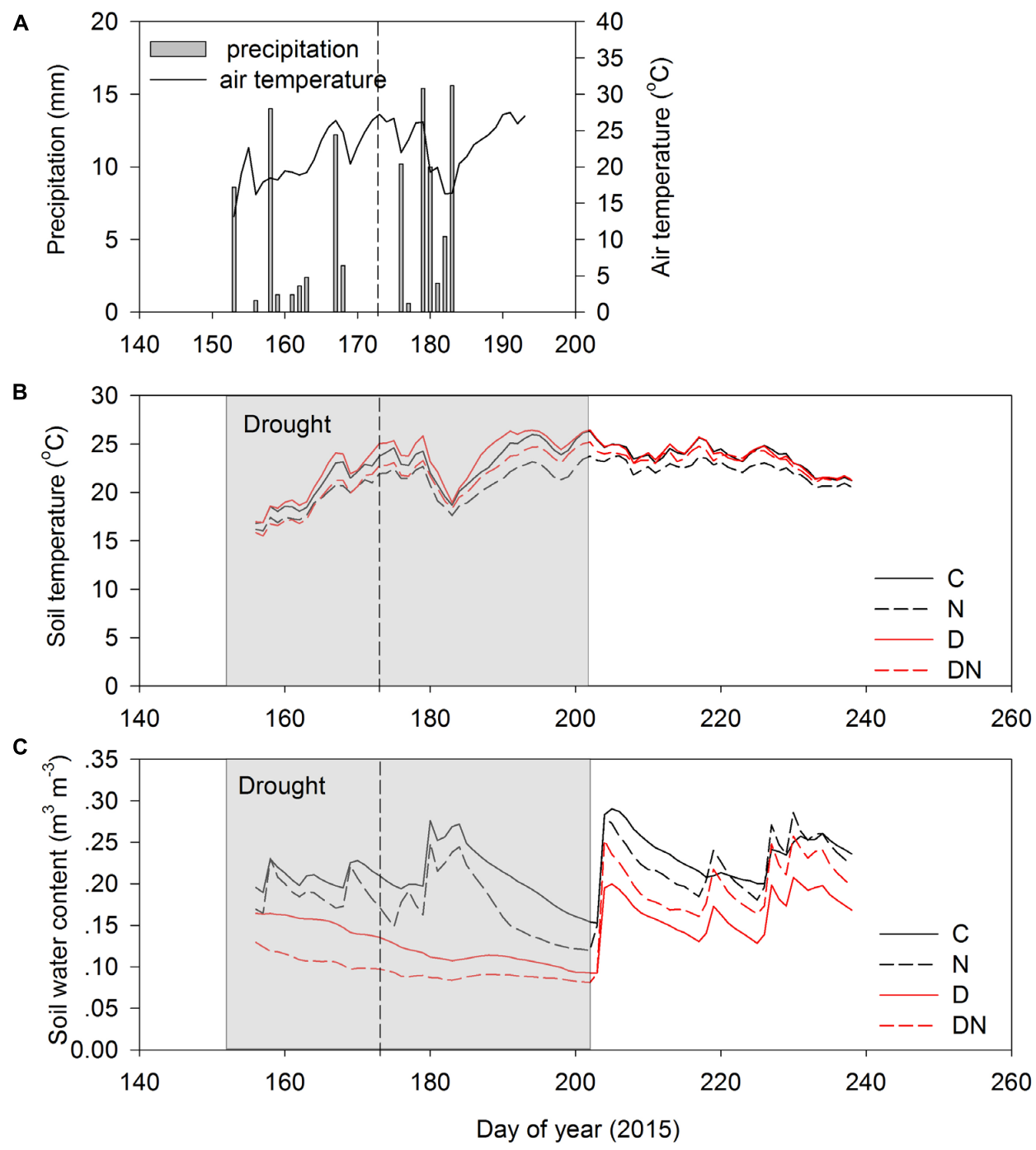

FIGURE 1 | Precipitation (A), soil temperature (0-10 cm depth) (B), and soil water content (0-10 depth) (C) for four treatments (C, control; N, nitrogen addition; D, drought; DN, nitrogen addition plus drought) during the growing season in 2015. Shaded area indicates a 51 days extreme drought event (DOY 152 to DOY 202). Vertical dashed lines indicate the middle of the drought period (DOY 173).

except DN treatment (solid line) and all the treatments (dash line) at the end of the drought period (DOY 196 in 2015).

\section{Ecosystem C Exchange}

The $\mathrm{N}$ addition treatment increased GEP, NEE, and WUE on days 173 and 196 in 2015 (Figure 4). The drought treatment had no significant effect on GEP, ER, and NEE on day 173 in 2015, whereas it significantly reduced GEP, ER, and NEE on day 196 in 2015 both in the fertilized or unfertilized plots (Figure 4). GEP, ER, NEE, and ET were lower on day 196 than on day 173 in 2015 (Figure 4 and Supplementary Table S3). The droughtinduced reductions in GEP and NEE were lower in the fertilized plots (Impact-D: $-27 \%,-29 \%$ ) than in the unfertilized plots (Impact-D: -34\%, -46\%) on day 173 in 2015 (Figures 4A,E). In contrast, the drought-induced changes in GEP and NEE in the fertilized plots (Impact-D: $-65 \%,-74 \%$ ) were greater than in the unfertilized plots (Impact-D: $-47 \%,-46 \%$ ) on day 196 in 2015 (Figures 4B,F). GEP and NEE were positively dependent on the aboveground phytomass (Figure 5). The correlations had greater values of $R^{2}$ when the DN treatment was excluded from the regression analysis (Figure 5).

\section{Species Richness and Diversity}

The number of plant species ranged from a minimum of 4 to a maximum of 8 depending on the treatments and observation date (Supplementary Figures S1A,B). There were no significant treatment differences in 2015 (Supplementary Figure S1A) and 2016 (Supplementary Figure S1B). Despite values of the Shannon-Wiener diversity index that were lower in the $\mathrm{N}$ plots compared to the C plots in 2015 and 2016 (Supplementary Figures S1C,D), the differences were not statistically significant. The drought treatment, both on its own and in combination with 

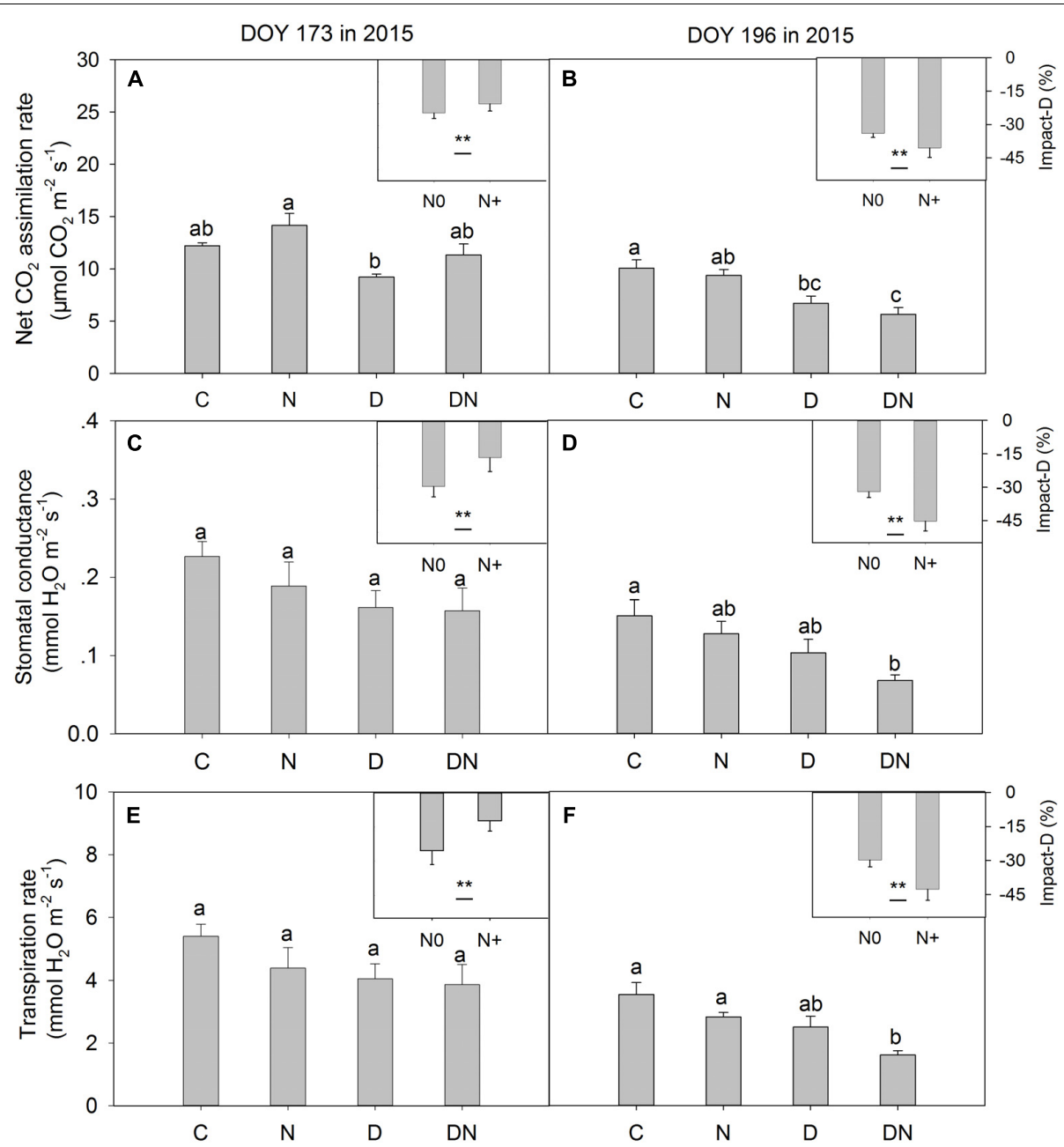

FIGURE 2 | Responses of leaf gas exchange parameters [(A,B) net $\mathrm{CO}_{2}$ assimilation rate, (C,D) stomatal conductance and (E,F) transpiration rate] in Leymus chinensis to four treatments (C, control; N, nitrogen addition; D, drought; DN, nitrogen addition plus drought) at the middle (DOY 173) and the end (DOY 196) of the drought period. Impact- $\mathrm{D}=\left(X_{D}-X_{C}\right) / X_{C} \times 100$, or $=\left(X_{D N}-X_{N}\right) / X_{N} \times 100$, where $X$ indicates net $\mathrm{CO}_{2}$ assimilation rate, stomatal conductance, or transpiration rate. Different letters and asterisk indicate significant differences between the treatments $(P<0.05)$. The error bars represent standard errors of means $(n=6)$.

the $\mathrm{N}$ addition treatment, did not significantly affect the diversity index during the observation period.

\section{Phytomass}

Compared to the $\mathrm{C}$ plots, aboveground phytomass in the $\mathrm{N}$ plots increased by $128 \%$ on day 196 in 2015 (Figure 6A) and 86\% in August 2016 (Figure 6B). Despite aboveground phytomass values that were lower (compared to the $\mathrm{C}$ plots) in the $\mathrm{D}$ plots, the differences were not significant in both 2015 (Figure 6A) and 2016 (Figure 6B). For fertilized plots, the drought treatment significantly reduced aboveground phytomass on day 196 in 2015 (Figure 6A). There were no significant differences in aboveground phytomass between the $\mathrm{N}$ and DN plots in 2016 (Figure 6B). Differences in the drought-induced reduction in aboveground phytomass between the fertilized and unfertilized plots were significant on day 196 in 2015, but not in August 2016 (Figures 6A,B). The drought treatment induced an increase in root phytomass, but the differences were not significant between the $\mathrm{C}$ and $\mathrm{D}$ plots or $\mathrm{N}$ and DN plots on day 196 in 2015 (Figure 6C). However, the percentage of the droughtinduced increase in root phytomass was greater in fertilized plots than in unfertilized plots in August 2016 (Figures 6C,D). On day 196 in 2015, as a result of drought impacts, the rootshoot ratio in the unfertilized and fertilized plots increased by 57 and 129\%, respectively (Figure 6E). Compared to the $\mathrm{N}$ addition treatment, drought caused the root-shoot ratio in the fertilized plots to increase by 104\% in August 2016 (Figure 6F).

\section{DISCUSSION}

\section{Leaf Photosynthetic Characteristics}

The drought treatment decreased $A$ on day 196 in 2015 (the end of the drought period), which was mainly attributed to the fact that the shortage of soil water induced a limitation of 


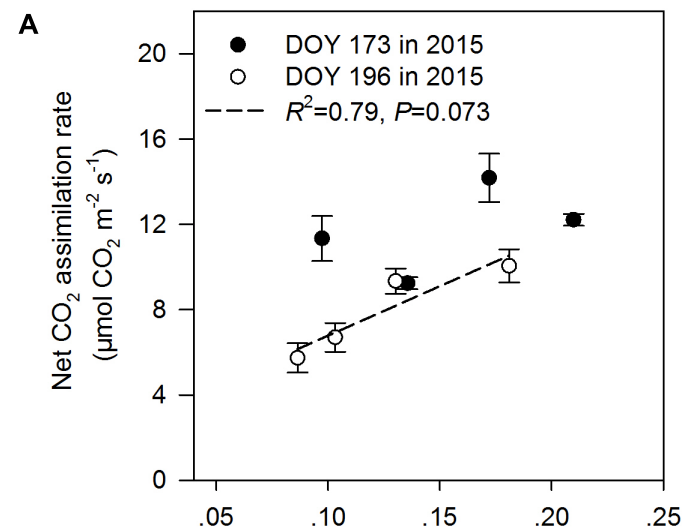

B

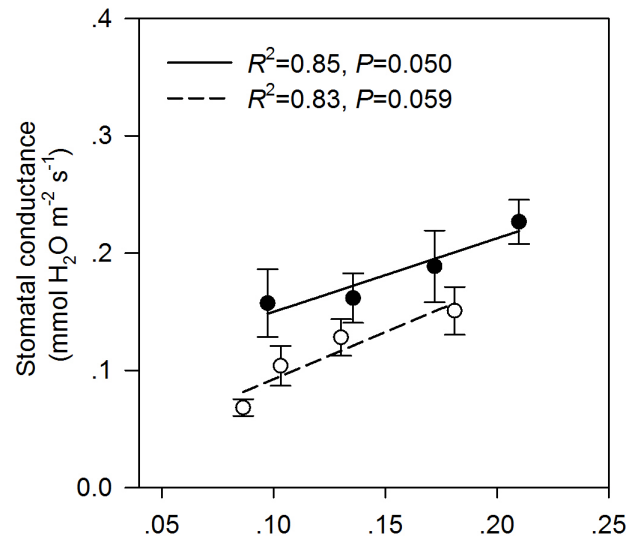

C

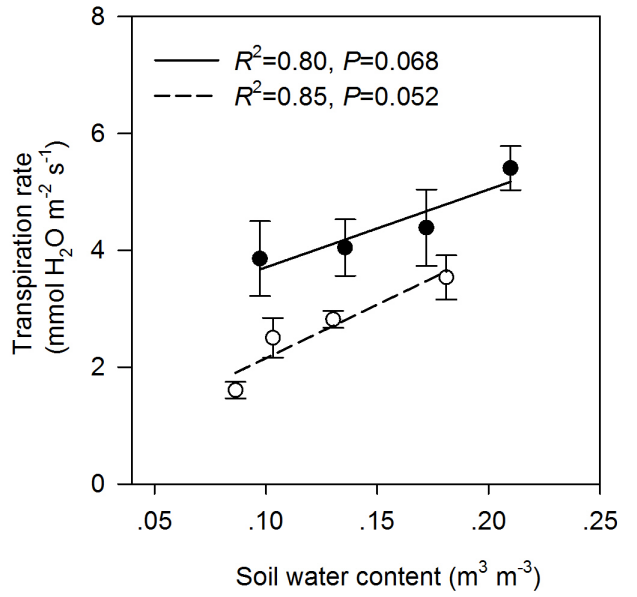

FIGURE 3 | Relationships between leaf gas exchange parameters [(A) net $\mathrm{CO}_{2}$ assimilation rate, (B) stomatal conductance, and (C) transpiration rate] and soil water content at the middle (DOY 173) and the end (DOY 196) of the drought period. The error bars represent standard errors of means $(n=6)$.

$\mathrm{CO}_{2}$ through the closure of stomata and metabolic constraints (Figure 2; Flexas et al., 2008). The above reasoning was also supported by the results inferred from our linear regression analysis (Figure 3). The regression model suggested that $A$ was controlled by the soil water content across different treatments. The drought-associated severe soil water shortage had negative effects on the $\mathrm{N}$ metabolism by regulating the activities of key enzymes involved in $\mathrm{N}$ assimilation and catabolism and led to

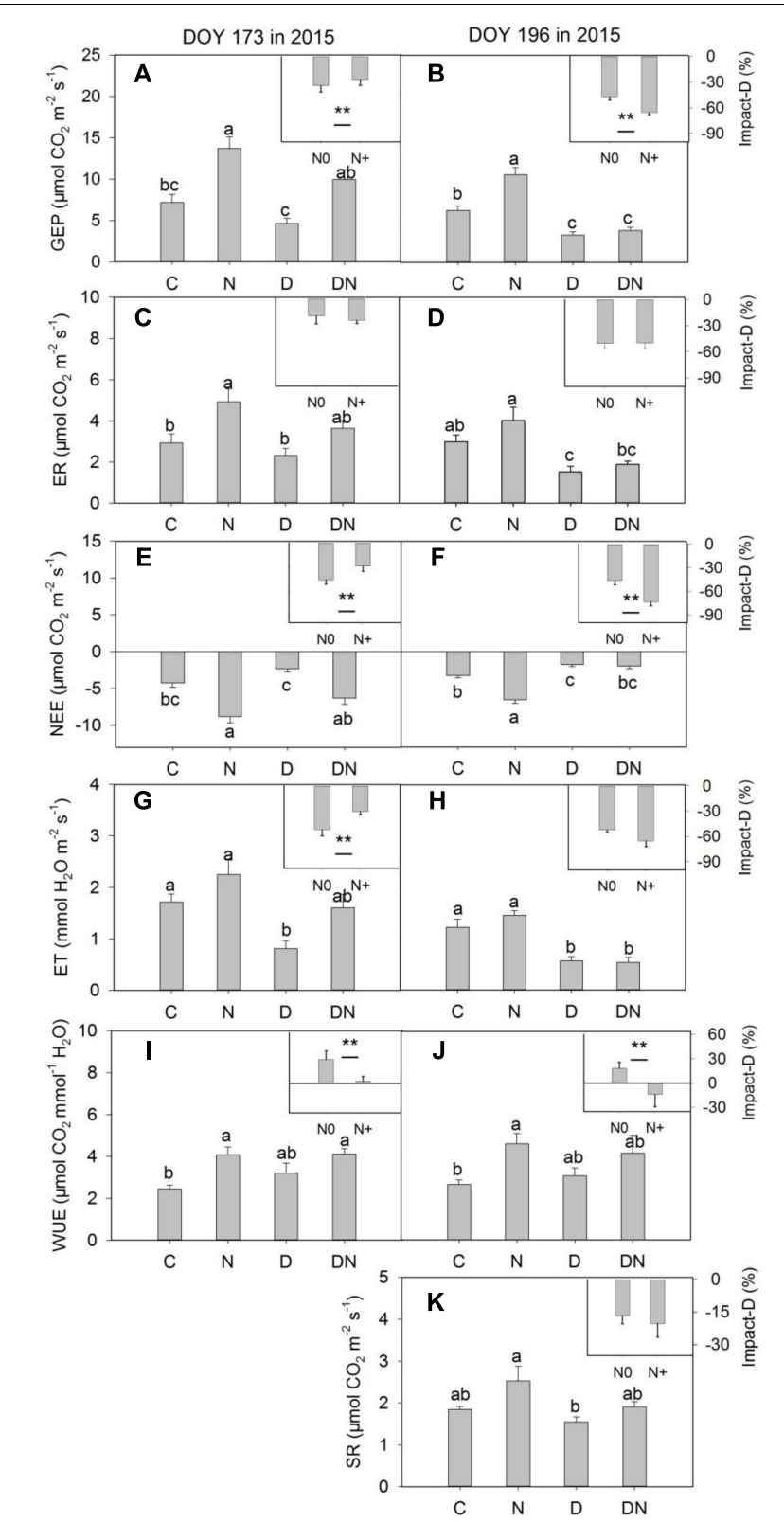

FIGURE 4 | Responses of (A,B) gross ecosystem productivity (GEP), (C,D) ecosystem respiration (ER), (E,F) net ecosystem $\mathrm{CO}_{2}$ exchange (NEE), (G,H) evapotranspiration $(E T),(\mathbf{I}, \mathbf{J})$ water-use efficiency $(\mathrm{WUE})$, (K) soil respiration (SR) to four treatments (C, control; N, nitrogen addition; D, drought; DN, nitrogen addition plus drought) at the middle (DOY 173) and the end (DOY 196) of the drought period. Impact- $D=\left(X_{D}-X_{C}\right) / X_{C} \times 100$, or $=\left(X_{D N}-X_{N}\right) / X_{N} \times 100$, where $X$ indicates GEP, ER, NEE, ET, WUE, and SR. Different letters and asterisk indicate significant differences between the treatments $(P<0.05)$. The error bars represent standard errors of means $(n=6)$.

damage to cell membranes and a reduction of photosynthetic capacity (Xu and Zhou, 2006). Moreover, the studied grassland has a sodic saline meadow soil with relatively high electrical conductivity (Supplementary Table S2) and degree of salinity, which may exacerbate the drought effect due to reduced soil 

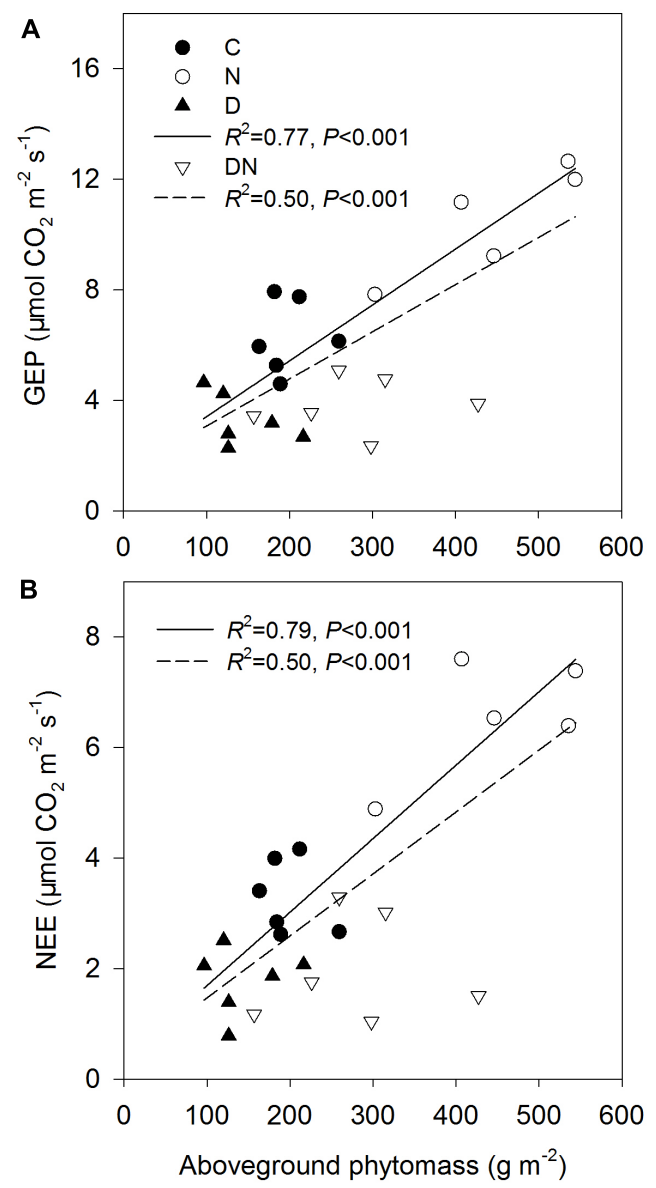

FIGURE 5 | Relationships between gross ecosystem productivity (GEP) (A) and ecosystem $\mathrm{CO}_{2}$ exchange (NEE) (B) and aboveground phytomass across all the treatments except DN treatment (solid line) and all the treatments (dash line) at the end of the drought period (DOY 196 in 2015).

available water. The soil water potential should be measured during the drought period in further research to understand the response mechanism of leaf photosynthetic characteristics to extreme drought. In general, $\mathrm{N}$ addition stimulates the net carbon assimilation rate as a result of the increase in leaf chlorophyll content (Evans, 1989). However, leaf carbon assimilation was not affected by $\mathrm{N}$ addition during the observation period in this study. Leaf carbon assimilation is sensitive to variations in light intensity, atmospheric moisture, and temperature (Creese et al., 2014). As such, the stimulating effect of the $\mathrm{N}$ addition treatment on $A$ might be not captured from the "snapshot" leaf gas exchange measurements.

The $\mathrm{N}$ addition treatment alleviated drought-induced suppression of $A, g_{s}$, and $T_{r}$ in the middle of the drought period, whereas it exacerbated drought-induced suppression of these photosynthetic characteristics at the end of the drought period. This is closely related to the change in soil water content during the drought period, seasonal changes in air temperature and the growth strategy of L. chinensis. In the early stages of drought, the amount of water in the soil was relatively sufficient. $\mathrm{N}$ addition could not only stimulate the net carbon assimilation rate (Evans, 1989) but also increase the drought tolerance of plants by preventing cell membrane damage and enhancing osmoregulation (Saneoka et al., 2004). Consequently, when the $\mathrm{N}$ addition and drought were combined, there was a reduced drought impact on leaf photosynthetic characteristics in this period. From the middle to the end of the drought period, the drought treatment did not cause a sharp decrease in soil water content, especially in the fertilized plots, which indicated the soil water contents were nearing the wilting point for L. chinensis. Compared to the D treatment, the plants in the DN treatment reached wilting point earlier and suffered a longer period of drought stress because of greater aboveground biomass associated higher transpiration. Meanwhile, the higher temperatures and radiation in July may have exacerbated drought stress in the DN communities that were already under pressure toward the end of the drought period. Furthermore, the soil water shortage is generally related to a reduction in plant-available soil N (Durand et al., 2010; Hofer et al., 2016). Thus, the $\mathrm{N}$ addition exacerbated drought-induced suppression of leaf photosynthetic characteristics in the second half of the drought event.

\section{Ecosystem $\mathbf{C}$ and Water Flux}

$\mathrm{N}$ addition stimulated plant growth and consequently enhanced GEP and net $\mathrm{C}$ uptake in this study. This is consistent with the findings of many others (Niu et al., 2010; Yan et al., 2011; EstopAragonés et al., 2016). Over the 4 years, $\mathrm{N}$ addition significantly stimulated growing-season net $\mathrm{C}$ uptake, on average, by $27 \%$ in a typical temperate steppe (Niu et al., 2010). Estop-Aragonés et al. (2016) also found that the manipulated $\mathrm{N}$ deposition treatment increased $\mathrm{CO}_{2}$ fluxes and GEP in mesocosms of 14 European peatlands. In contrast, drought decreased GEP, ER and net $\mathrm{C}$ uptake, which is in line with a synthesis study suggesting that experimentally reduced precipitation suppressed aboveground net primary production and net $\mathrm{C}$ uptake (Wu et al., 2011). The response of GEP and net $C$ uptake to different manipulated precipitation and $\mathrm{N}$ addition treatments depends on the changes in aboveground phytomass and species composition (Wu et al., 2011; Yan et al., 2011; Wang et al., 2015). However, the studied grassland was dominated by L. chinensis, which caused a non-significant change in functional groups under different treatments. Thus, the physiological traits of dominant species may play an important role in ecosystem $\mathrm{C}$ exchange (Wang et al., 2007). This inference was supported by the result of our linear regression analysis. The values of $R^{2}$ of the linear model for explaining the variation of GEP and net $C$ uptake across all the treatments except the DN treatment were higher compared to those across all the treatments (Figure 5). It is noticeable that the aboveground phytomass in the DN treatment was still higher than that of the $\mathrm{C}$ or $\mathrm{D}$ treatment, although drought-induced suppression was exacerbated by the $\mathrm{N}$ addition treatment. The reason could be that compared to aboveground phytomass, $A$ was more sensitive to the decrease in the soil water content and the response of aboveground phytomass on the decrease in the soil water content may have a time delay. As such, the relatively low GEP and net $\mathrm{C}$ uptake in the DN treatment 


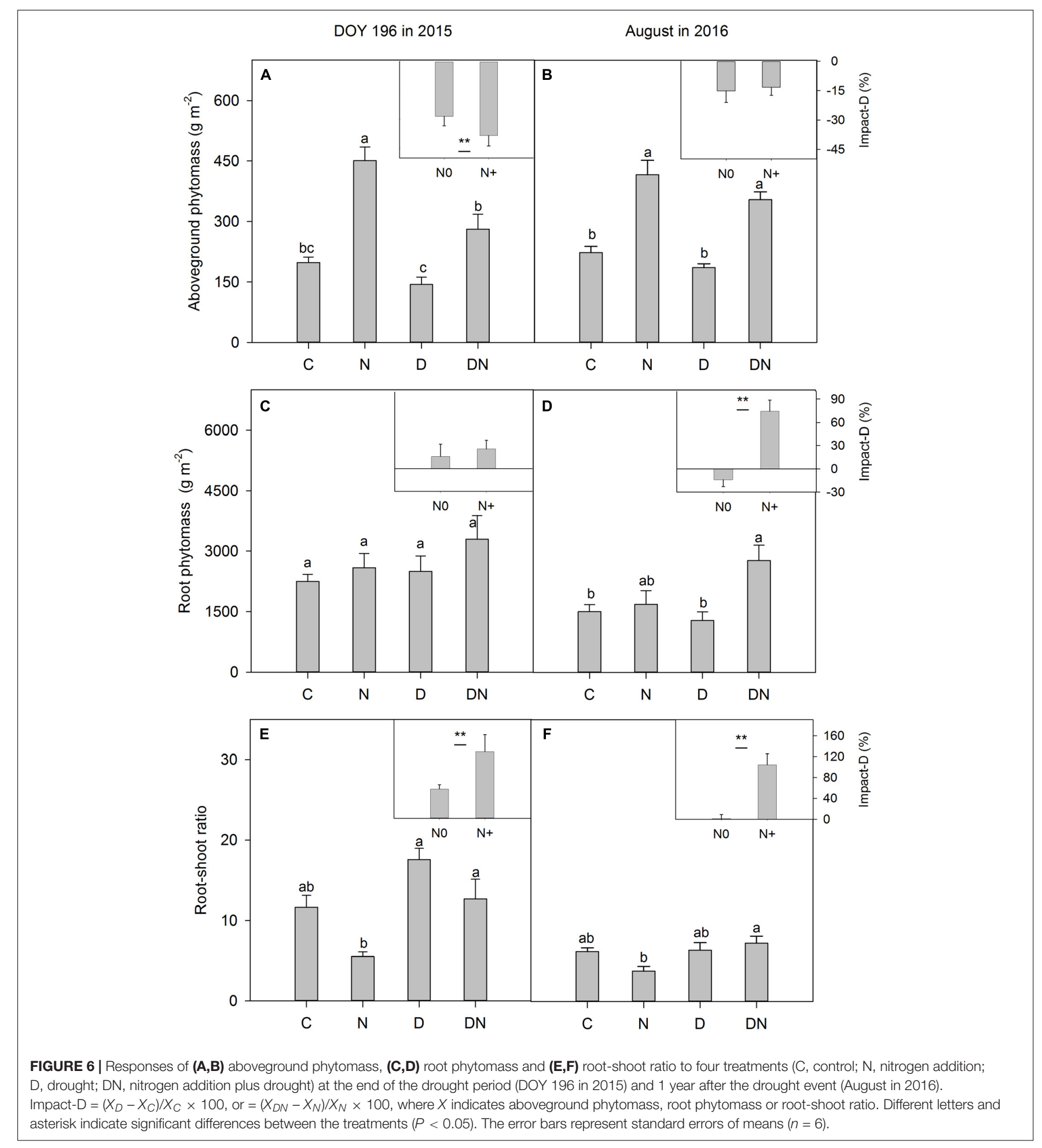

may be mainly attributed to the decrease in A. Although the response of ecosystem $\mathrm{C}$ exchange to $\mathrm{N}$ addition, drought and the combination of $\mathrm{N}$ addition and drought treatments was in line with expectations, caution is required for the interpretation of these results as these were only snapshots of the drought response processes.
Consistent with the previous study (Tian et al., 2016), we found that the $\mathrm{N}$ addition treatment increased WUE during the measurement period. However, the combination of $\mathrm{N}$ addition and drought treatment had no significant effects on WUE compared to the $\mathrm{D}$ treatment during the observation period $(P=0.27,0.55$; Figures $4 \mathbf{I}, \mathbf{J})$, which was contrary to our 
expectation. As such, the fact that $\mathrm{N}$ addition treatment alleviated drought-induced suppression of the $\mathrm{CO}_{2}$ exchange at leaf and ecosystem levels in the middle of the drought period cannot be attributed to the change in WUE.

\section{Phytomass Production and Allocation}

$\mathrm{N}$ addition often has a fertilization effect, which increases aboveground phytomass and increases light limitation (reduced transmission of photosynthetically active radiation to ground level), further causing declines in plant diversity (Borer et al., 2014; Hautier et al., 2014). Consistent with the results of previous studies (Henry et al., 2015; Moinet et al., 2017), we found that the $\mathrm{N}$ addition treatment stimulated aboveground phytomass production. However, the diversity index was not affected by the treatments of drought, $\mathrm{N}$ addition and their interaction. It is probable that L. chinensis has strong adaptability and tolerance to drought, waterlogging and salt-alkaline stress and is the absolute dominant species in our study area (Chen and Wang, 2009; Wang D. et al., 2017). Therefore, the species richness and Shannon-Wiener index were very low in all treatments. The drought-induced reduction in aboveground phytomass has been extensively reported (VanderWeide and Hartnett, 2015; Knapp et al., 2017). Our results showed that the D treatment decreased the aboveground phytomass, whereas this effect was not statistically significant, which was contrary to our expectation and inconsistent with the results of previous studies. This indicates that the aboveground productivity of $L$. chinensis meadow was highly resistant to a single extreme drought event.

Drought-induced suppression of aboveground phytomass was exacerbated by the $\mathrm{N}$ addition treatment. Our result was consistent with previous studies (Friedrich et al., 2012; Southon et al., 2012; Dziedek et al., 2016). The accelerated aboveground productivity of a perennial grass (Molinia caerulea) under $\mathrm{N}$ fertilization resulted in higher drought susceptibility (Friedrich et al., 2012). In a lowland heath, $\mathrm{N}$ appeared to affect the sensitivity of Calluna vulgaris to climate stress, with greater levels of shoot browning in plots receiving $\mathrm{N}$ addition during dry years (Southon et al., 2012). The shortage of soil water induced a reduction in the growth rate because the meristems become less active and because of lower $A$, decreases in leaf expansion, and a shift in C allocation (Figure 6; De Boeck et al., 2016), which eventually caused earlier leaf senescence, mortality of tissues and reduction in aboveground phytomass production. Because the leaves were not withered completely during the drought period, and pure biomass and necromass were difficult to separate, we could not assess differences in drought-induced tissue senescence between the fertilized and unfertilized treatments. The effects of drought on plant aboveground productivity in the fertilized or unfertilized plots could be underestimated in this study.

In August 2016 (1 year after the drought event), the effects of drought on aboveground phytomass were negligible both in the fertilized or unfertilized plots. This may be attributed to plants compensatory growth following release from stress (Retuerto and Woodward, 2001). On the other hand, as a result of drought impacts, the root phytomass in the unfertilized and fertilized plots increased by 11 and 47\%, respectively, which may contribute to the post-drought recovery of grassland productivity. The fresh and old photosynthetic products in aboveground phytomass can be allocated to roots to obtain more available water under extreme drought stress (Figure 6; Hasibeder et al., 2015). More aboveground phytomass in the fertilized plots could stimulate this effect. An increase in the root-shoot ratio and root phytomass in the DN treatment at the end of the drought period in 2015 may facilitate the enhancement of clonal expansion (Zhu, 2004) and increase the water obtained after rewetting, which promoted recovery in aboveground phytomass. The results of a study in the Mongolian steppe have also suggested that increasing $\mathrm{N}$ deposition enhanced post-drought recovery of grassland productivity, and the increase in productivity was associated with an increase in shoot emergence of a perennial herb, Artemisia adamsii (Kinugasa et al., 2012). It is noticeable that this effect (drought-induced increase in root phytomass and the root-shoot ratio in the fertilized plots) persisted 1 year after the drought treatment. This response has not been found in other studies, as available data on the effects of the combination of extreme drought and $\mathrm{N}$ addition on grassland ecosystems are limited. Nevertheless, grasses experiencing drought can retain a long-lasting stress imprint (Walter et al., 2011; Fuchslueger et al., 2016). Some studies reported that the projected increase in the frequency of drought and rewetting events could enhance the resistance of organisms to similar disturbances due to improved photoprotection (Walter et al., 2011, 2013). Wang S. et al. (2017) also found that exposure to inundation or drought conditions can induce physiological or morphological changes in plants that improve tolerance for either extreme condition later. Our results show that $\mathrm{N}$ addition exacerbated drought-induced suppression of aboveground phytomass under extreme drought stress, but may enhance drought resistance to further drought events due to increased root phytomass and an increased root-shoot ratio. More research is needed to confirm this inference.

Similar to leaf gas exchange and GEP and net C uptake, the effect of drought on aboveground phytomass was exacerbated by the $\mathrm{N}$ addition treatment at the end of the drought period. These results suggest that $\mathrm{N}$ addition enhances the drought susceptibility of the L. chinensis meadow ecosystem at different hierarchical levels under extreme drought stress, including leaf-level responses $\left(A, g_{s}\right.$, and $\left.T_{r}\right)$, communitylevel responses (aboveground phytomass) and ecosystem-level responses (GEP and NEE). The response of ecosystem functions at higher ecological levels may be resulted from that of plant ecophysiological responses at the lower hierarchical levels (Hoover et al., 2014; Hoover et al., 2017).

\section{CONCLUSION}

The $\mathrm{N}$ addition treatment alleviated drought-induced suppression of the $\mathrm{CO}_{2}$ exchange at leaf and ecosystem levels in the middle of the drought period, whereas it exacerbated drought-induced suppression of the $\mathrm{CO}_{2}$ exchange and aboveground phytomass on the community level with prolonged drought. The traits of L. chinensis and its ecophysiological response at the lower hierarchical levels to multiple global change drivers determined the response of ecosystem function 
at higher ecological levels. These findings enable us to better understand the effect of the combination of different global change drivers on L. chinensis ecosystem functions. Furthermore, $\mathrm{N}$ addition may enhance the drought resistance of the L. chinensis meadow ecosystem to further drought events by increasing carbon allocation to roots and therefore root-shoot ratios.

\section{AUTHOR CONTRIBUTIONS}

WS and YW designed the experiment. YW, BM, and SZ performed the field and laboratory work, and BS analyzed the data. BS and WS wrote the manuscript.

\section{FUNDING}

This study was financially supported by the National Key Basic Research Program of China (2015CB150800), National Natural

\section{REFERENCES}

Bai, Y., Wu, J., Clark, C. M., Naeem, S., Pan, Q., Huang, J., et al. (2010). Tradeoffs and thresholds in the effects of nitrogen addition on biodiversity and ecosystem functioning: evidence from inner Mongolia grasslands. Glob. Change Biol. 16, 358-372. doi: 10.1111/j.1365-2486.2009.01950.x

Borer, E. T., Seabloom, E. W., Gruner, D. S., Harpole, W. S., Hillebrand, H., Lind, E. M., et al. (2014). Herbivores and nutrients control grassland plant diversity via light limitation. Nature 508, 517-520. doi: 10.1038/nature13144

Chen, L., and Wang, R. (2009). Anatomical and physiological divergences and compensatory effects in two Leymus chinensis (Poaceae) ecotypes in Northeast China. Agric. Ecosyst. Environ. 134, 46-52. doi: 10.1016/j.agee.2009.05.015

Creese, C., Oberbauer, S., Rundel, P., and Sack, L. (2014). Are fern stomatal responses to different stimuli coordinated? Testing responses to light, vapor pressure deficit, and $\mathrm{CO}_{2}$ for diverse species grown under contrasting irradiances. New Phytol. 204, 92-104. doi: 10.1111/nph.12922

Cui, H. Y., Wang, Y. B., Jiang, Q., Chen, S. P., Ma, J. Y., and Sun, W. (2015). Carbon isotope composition of nighttime leaf-respired $\mathrm{CO}_{2}$ in the agriculturalpastoral zone of the Songnen Plain, Northeast China. PLoS One 10:e137575. doi: 10.1371/journal.pone.0137575

De Boeck, H. J., Bassin, S., Verlinden, M., Zeiter, M., and Hiltbrunner, E. (2016). Simulated heat waves affected alpine grassland only in combination with drought. New Phytol. 209, 531-541. doi: 10.1111/nph.13601

Durand, J. L., Gonzalez-Dugo, V., and Gastal, F. (2010). How much do water deficits alter the nitrogen nutrition status of forage crops? Nutr. Cycl. Agroecosyst. 88, 231-243. doi: 10.1007/s10705-009-9330-3

Dziedek, C., Härdtle, W., von Oheimb, G., and Fichtner, A. (2016). Nitrogen addition enhances drought sensitivity of young deciduous tree species. Front. Plant Sci. 7:1100. doi: 10.3389/fpls.2016.01100

Estop-Aragonés, C., Zajạc, K., and Blodau, C. (2016). Effects of extreme experimental drought and rewetting on $\mathrm{CO}_{2}$ and $\mathrm{CH}_{4}$ exchange in mesocosms of fourteen European peatlands with different nitrogen and sulfur deposition. Glob. Change Biol. 22, 2285-2300. doi: 10.1111/gcb.13228

Evans, J. R. (1989). Photosynthesis and nitrogen relationships in leaves of $\mathrm{C}_{3}$ plants. Oecologia 78, 9-19. doi: 10.1007/BF00377192

Flexas, J., Ribas-Carbó, M., Diaz-Espejo, A., Galmés, J., and Medrano, H. (2008). Mesophyll conductance to $\mathrm{CO}_{2}$ : current knowledge and future prospects. Plant Cell Environ. 31, 602-621. doi: 10.1111/j.1365-3040.2007.01757.x

Friedrich, U., von Oheimb, G., Kriebitzsch, W. U., Schleßelmann, K., Weber, M. S., and Härdtle, W. (2012). Nitrogen deposition increases susceptibility to drought-experimental evidence with the perennial grass Molinia caerulea (L.) Moench. Plant Soil 353, 59-71. doi: 10.1007/s11104-011-1008-3

Fuchslueger, L., Bahn, M., Hasibeder, R., Kienzl, S., Fritz, K., Schmitt, M., et al. (2016). Drought history affects grassland plant and microbial carbon
Science Foundation of China (31570470, 31700449, 31270445), the Fundamental Research Funds for the Central Universities (2412016KJ008) and China Postdoctoral Science Foundation (2017M611300).

\section{ACKNOWLEDGMENTS}

We are grateful for the support of Songnen Grassland Ecology Research Station. We want to thank Yanan Li for help during laboratory analyses.

\section{SUPPLEMENTARY MATERIAL}

The Supplementary Material for this article can be found online at: https://www.frontiersin.org/articles/10.3389/fpls.2018.00254/ full\#supplementary-material

turnover during and after a subsequent drought event. J. Ecol. 104, 1453-1465. doi: 10.1111/1365-2745.12593

Greaver, T. L., Clark, C. M., Compton, J. E., Vallano, D., Talhelm, A. F., Weaver, C. P., et al. (2016). Key ecological responses to nitrogen are altered by climate change. Nat. Clim. Change 6, 836-843. doi: 10.1038/nclimate 3088

Hasibeder, R., Fuchslueger, L., Richter, A., and Bahn, M. (2015). Summer drought alters carbon allocation to roots and root respiration in mountain grassland. New Phytol. 205, 1117-1127. doi: 10.1111/nph.13146

Hautier, Y., Seabloom, E. W., Borer, E. T., Adler, P. B., Harpole, W. S., Hillebrand, H., et al. (2014). Eutrophication weakens stabilizing effects of diversity in natural grasslands. Nature 508, 521-525. doi: 10.1038/nature 13014

He, C. E., Liu, X. J., Andreas, F., and Zhang, F. S. (2007). Quantifying the total airborne nitrogen input into agroecosystems in the North China plain. Agric. Ecosyst. Environ. 121, 395-400. doi: 10.1016/j.agee.2006.12.016

Henry, H. A., Hutchison, J. S., Kim, M. K., and McWhirter, B. D. (2015). Context matters for warming: interannual variation in grass biomass responses to 7 years of warming and $\mathrm{N}$ addition. Ecosystems 18, 103-114. doi: 10.1007/s10021-0149816-y

Hofer, D., Suter, M., Haughey, E., Finn, J. A., Hoekstra, N. J., Buchmann, N., et al. (2016). Yield of temperate forage grassland species is either largely resistant or resilient to experimental summer drought. J. Appl. Ecol. 53, 1023-1034. doi: 10.1111/1365-2664.12694

Hoover, D. L., Duniway, M. C., and Belnap, J. (2015). Pulse-drought atop pressdrought: unexpected plant responses and implications for dryland ecosystems. Oecologia 179, 1211-1221. doi: 10.1007/s00442-015-3414-3

Hoover, D. L., Duniway, M. C., and Belnap, J. (2017). Testing the apparent resistance of three dominant plants to chronic drought on the Colorado Plateau. J. Ecol. 105, 152-162. doi: 10.1111/1365-2745.12647

Hoover, D. L., Knapp, A. K., and Smith, M. D. (2014). Resistance and resilience of a grassland ecosystem to climate extremes. Ecology 95, 2646-2656. doi: 10.1890/ $13-2186.1$

Hufkens, K., Keenan, T. F., Flanagan, L. B., Scott, R. L., Bernacchi, C. J., Joo, E., et al. (2016). Productivity of North American grasslands is increased under future climate scenarios despite rising aridity. Nat. Clim. Change 6, 710-714. doi: $10.1038 /$ nclimate2942

IPCC (2013). Climate Change 2013: The Physical Science Basis Contribution of Working Group I to the Fifth Assessment Report of the Intergovernmental Panel on Climate Change. Cambridge: Cambridge University Press.

Kinugasa, T., Tsunekawa, A., and Shinoda, M. (2012). Increasing nitrogen deposition enhances post-drought recovery of grassland productivity in the Mongolian steppe. Oecologia 170, 857-865. doi: 10.1007/s00442-0122354-4 
Knapp, A. K., Beier, C., Briske, D. D., Classen, A. T., Luo, Y., Reichstein, M., et al. (2008). Consequences of more extreme precipitation regimes for terrestrial ecosystems. BioScience 58, 811-821. doi: 10.1641/B580908

Knapp, A. K., Ciais, P., and Smith, M. D. (2017). Reconciling inconsistencies in precipitation-productivity relationships: implications for climate change. New Phytol. 214, 41-47. doi: 10.1111/nph.14381

Krebs, C. J. (1985). Ecology: The Experimental Analysis of Distributions and Abundance, 3rd Edn. New York, NY: Harper and Row Publishers.

Ladwig, L. M., Collins, S. L., Swann, A. L., Xia, Y., Allen, M. F., and Allen, E. B. (2012). Above-and belowground responses to nitrogen addition in a Chihuahuan desert grassland. Oecologia 169, 177-185. doi: 10.1007/s00442011-2173-z

LeBauer, D. S., and Treseder, K. K. (2008). Nitrogen limitation of net primary productivity in terrestrial ecosystems is globally distributed. Ecology 89, 371379. doi: 10.1890/06-2057.1

Lee, M. A., Manning, P., Walker, C. S., and Power, S. A. (2014). Plant and arthropod community sensitivity to rainfall manipulation but not nitrogen enrichment in a successional grassland ecosystem. Oecologia 176, 1173-1185. doi: 10.1007/ s00442-014-3077-5

Lu, C., Tian, H., Liu, M., Ren, W., Xu, X., Chen, G., et al. (2012). Effect of nitrogen deposition on China's terrestrial carbon uptake in the context of multifactor environmental changes. Ecol. Appl. 22, 53-75. doi: 10.1890/10-1685.1

Meyer-Grünefeldt, M., Calvo, L., Marcos, E., von Oheimb, G., and Härdtle, W. (2015). Impacts of drought and nitrogen addition on Calluna heathlands differ with plant life-history stage. J. Ecol. 103, 1141-1152. doi: 10.1111/1365-2745. 12446

Moinet, G. Y. K., Cieraad, E., Turnbull, M. H., and Whitehead, D. (2017). Effects of irrigation and addition of nitrogen fertiliser on net ecosystem carbon balance for a grassland. Sci. Total Environ. 579, 1715-1725. doi: 10.1016/j.scitotenv. 2016.11.199

Niu, S. L., Wu, M. Y., Han, Y., Xia, J. Y., Zhang, Z., Yang, H. J., et al. (2010). Nitrogen effects on net ecosystem carbon exchange in a temperate steppe. Glob. Change Biol. 16, 144-155. doi: 10.1111/j.1365-2486.2009.01894.x

Peñuelas, J., Sardans, J., Filella, I., Estiarte, M., Llusià, J., Ogaya, R., et al. (2017). Assessment of the impacts of climate change on Mediterranean terrestrial ecosystems based on data from field experiments and long-term monitored field gradients in Catalonia. Environ. Exp. Bot. (in press). doi: 10.1016/j.envexpbot.2017.05.012

Retuerto, R., and Woodward, F. I. (2001). Compensatory responses in growth and fecundity traits of Sinapis alba L. following release from wind and density stress. Int. J. Plant Sci. 162, 171-179. doi: 10.1086/317904

Reyer, C. P. O., Leuzinger, S., Rammig, A., Wolf, A., Bartholomeus, R. P., Bonfante, A., et al. (2013). A plant's perspective of extremes: terrestrial plant responses to changing climatic variability. Glob. Change Biol. 19, 75-89. doi: $10.1111 /$ gcb. 12023

Saneoka, H., Moghaieb, R. E. A., Premachandra, G. S., and Fujita, K. (2004). Nitrogen nutrition and water stress effects on cell membrane stability and leaf water relations in Agrostis palustris Huds. Environ. Exp. Bot. 52, 131-138. doi: 10.1016/j.envexpbot.2004.01.011

Smith, M. D. (2011). The ecological role of climate extremes: current understanding and future prospects. J. Ecol. 99, 651-655. doi: 10.1111/j.13652745.2011.01833.x

Smith, M. D., Knapp, A. K., and Collins, S. L. (2009). A framework for assessing ecosystem dynamics in response to chronic resource alterations induced by global change. Ecology 90, 3279-3289. doi: 10.1890/08-1815.1

Smith, N. G., Schuster, M. J., and Dukes, J. S. (2016). Rainfall variability and nitrogen addition synergistically reduce plant diversity in a restored tall grass prairie. J. Appl. Ecol. 53, 579-586. doi: 10.1111/1365-2664.12593

Song, M. H., and Yu, F. H. (2015). Reduced compensatory effects explain the nitrogen-mediated reduction in stability of an alpine meadow on the Tibetan Plateau. New Phytol. 207, 70-77. doi: 10.1111/nph.13329

Southon, G. E., Green, E. R., Jones, A. G., Barker, C. G., and Power, S. R. (2012). Long-term nitrogen additions increase likelihood of climate stress and affect recovery from wildfire in a lowland heath. Glob. Change Biol. 18, 2824-2837. doi: 10.1111/j.1365-2486.2012.02732.x

Tian, D., Niu, S., Pan, Q., Ren, T., Chen, S., Bai, Y., et al. (2016). Nonlinear responses of ecosystem carbon fluxes and water-use efficiency to nitrogen addition in Inner Mongolia grassland. Funct. Ecol. 30, 490-499. doi: 10.1111/ 1365-2435.12513

VanderWeide, B. L., and Hartnett, D. C. (2015). Belowground bud bank response to grazing under severe, short-term drought. Oecologia 178, 795-806. doi: 10.1007/s00442-015-3249-y

Walter, J., Jentsch, A., Beierkuhnlein, C., and Kreyling, J. (2013). Ecological stress memory and cross stress tolerance in plants in the face of climate extremes. Environ. Exp. Bot. 94, 3-8. doi: 10.1016/j.envexpbot.2012.02.009

Walter, J., Nagy, L., Hein, R., Rascher, U., Beierkuhnlein, C., Willner, E., et al. (2011). Do plants remember drought? Hints towards a drought-memory in grasses. Environ. Exp. Bot. 71, 34-40. doi: 10.1016/j.envexpbot.2010. 10.020

Wang, D., Du, J., Zhang, B., Ba, L., and Hodgkinson, K. C. (2017). Grazing intensity and phenotypic plasticity in the clonal grass Leymus chinensis. Rangeland Ecol. Manag. 70, 740-747. doi: 10.1016/j.rama.2017.06.011

Wang, S., Callaway, R. M., Zhou, D. W., and Weiner, J. (2017). Experience of inundation or drought alters the responses of plants to subsequent water conditions. J. Ecol. 105, 176-187. doi: 10.1111/1365-2745.12649

Wang, Y., Jiang, Q., Yang, Z., Sun, W., and Wang, D. (2015). Effects of water and nitrogen addition on ecosystem carbon exchange in a meadow steppe. PLoS One 10:e0127695. doi: 10.1371/journal.pone.0127695

Wang, Y., Yu, S., and Wang, J. (2007). Biomass-dependent susceptibility to drought in experimental grassland communities. Ecol. Lett. 10, 401-410. doi: 10.1111/j. 1461-0248.2007.01031.x

Wu, Z., Dijkstra, P., Koch, G. W., Peñuelas, J., and Hungate, B. A. (2011). Responses of terrestrial ecosystems to temperature and precipitation change: a metaanalysis of experimental manipulation. Glob. Change Biol. 17, 927-942. doi: 10.1111/j.1365-2486.2010.02302.x

Xu, Z., Ren, H., Cai, J., Wang, R., Li, M. H., Wan, S., et al. (2014). Effects of experimentally-enhanced precipitation and nitrogen on resistance, recovery and resilience of a semi-arid grassland after drought. Oecologia 176, 1187-1197. doi: 10.1007/s00442-014-3081-9

$\mathrm{Xu}, \mathrm{Z}$. Z., and Zhou, G. S. (2006). Nitrogen metabolism and photosynthesis in Leymus chinensis in response to long-term soil drought. J. Plant Growth Regul. 25, 252-266. doi: 10.1007/s00344-006-0043-4

Yan, L., Chen, S., Huang, J., and Lin, G. (2011). Increasing water and nitrogen availability enhanced net ecosystem $\mathrm{CO}_{2}$ assimilation of a temperate semiarid steppe. Plant Soil 349, 227-240. doi: 10.1007/s11104-011-0864-1

Yi, C., Pendall, E., and Ciais, P. (2015). Focus on extreme events and the carbon cycle. Environ. Res. Lett. 10:070201. doi: 10.1088/1748-9326/10/7/0 70201

Zhang, N., Guo, R., Song, P., Guo, J., and Gao, Y. (2013). Effects of warming and nitrogen deposition on the coupling mechanism between soil nitrogen and phosphorus in Songnen Meadow Steppe, northeastern China. Soil Biol. Biochem. 65, 96-104. doi: 10.1016/j.soilbio.2013.05.015

Zhong, S., Chai, H., Xu, Y., Li, Y., Ma, J. Y., and Sun, W. (2017). Drought sensitivity of the carbon isotope composition of leaf dark-respired $\mathrm{CO}_{2}$ in $\mathrm{C}_{3}$ (Leymus chinensis) and $\mathrm{C}_{4}$ (Chloris virgata and Hemarthria altissima) grasses in Northeast China. Front. Plant Sci. 8:1996. doi: 10.3389/fpls.2017.01996

Zhu, K., Chiariello, N. R., Tobeck, T., Fukami, T., and Field, C. B. (2016). Nonlinear, interacting responses to climate limit grassland production under global change. Proc. Natl. Acad. Sci. U.S.A. 113, 10589-10594. doi: 10.1073/ pnas. 1606734113

Zhu, T. C. (2004). Yang-cao Biological Ecology (in Chinese). Changchun: Jilin Science and Technology Press.

Conflict of Interest Statement: The authors declare that the research was conducted in the absence of any commercial or financial relationships that could be construed as a potential conflict of interest.

Copyright (c) 2018 Shi, Wang, Meng, Zhong and Sun. This is an open-access article distributed under the terms of the Creative Commons Attribution License (CC BY). The use, distribution or reproduction in other forums is permitted, provided the original author(s) and the copyright owner are credited and that the original publication in this journal is cited, in accordance with accepted academic practice. No use, distribution or reproduction is permitted which does not comply with these terms. 